\begin{tabular}{ll}
\hline \hline MINING AND METALLURGY INSTITUTE BOR & ISSN: 2334-8836 (Štampano izdanje) \\
UDK: 622 & ISSN: 2406-1395 (Online) \\
\hline \hline
\end{tabular}

\title{
SPATIAL AND TIME ASPECTS OF THE ANALYSIS OF POLLUTANTS IN THE RIVER WATER AND ITS SEDIMENTS
}

\begin{abstract}
The main objective of this study was to determine whether there are the spatial and temporal changes in physico-chemical properties of water and concentrations of heavy metals in water and sediment of the River Ibar upstream and downstream of Kosovska Mitrovica and Kraljevo. The following physicochemical parameters were determined: $\mathrm{pH}$, electrical conductivity, suspended matter content, biological oxygen demand, chemical oxygen demand, total organic carbon, contents of nitrates, ammonium ion, total phosphorous, sulphates. Concentrations of heavy metals in water and sediment samples were determined using an inductively coupled plasma optical emission spectrometry (ICP-OES) using a SPECTRO AR COS instrument. The water of the Ibar River after flowing through Kraljevo shows a higher degree of pollution than in Kosovska Mitrovica. However, the water upstream and downstream of Kraljevo is of similar quality indicating that the pollution source is not located in Kraljevo, but along the river section between the two towns. This study has also proved that the water quality in Kraljevo did not significantly change during the period 2010-2016. The highest concentrations of nitrates, nitrites, ortophosphates and ammonium ion are found in colder months. During spring-summer change electrical conductivity, $\mathrm{pH}$ and concentration of sulphates has most prominent change in the analyzed Ibar River water in Kraljevo.
\end{abstract}

Keywords: inorganic pollutants, river water, urban pollution, environment

\section{INTRODUCTION}

Urban development, which is largely an irreversible process, is one of the major driving forces of change of Earth's surface. It has an adverse effect of river flowing through the towns which are inevitably changed regarding the channel morphology and water quality. Municipalities and industry are a constant pollution source, while the surface runoff is a seasonal occurrence and depends on the climate characteristics of the basin [1].

Determining the degree of surface water contamination by numerous physical agents and chemical substances has become a growing health and general social problem $[2,3]$. Organic chemicals and heavy metals do not necessarily remain at one place but can be transported by the air or water throughout the environment [4].

In order to ensure a proper evaluation of the environmental status of a watercourse and application the environmental protection policies, a constant monitoring of the environmental parameters has to be applied. Heavy metals can enter a river through the natural sources mainly during the weathering of rock and soil or anthropogenic sources such as the industry, agriculture or

\footnotetext{
*University of Pristina, Faculty of Economics, Kolasinska 156, 38220 Kosovska Mitrovica, Serbia, e-mail: zoran.milicevic@pr.ac.rs

** Public Health Institute, Slobodana Penezica 16, 36000 Kraljevo, Serbia
} 
municipal waste, and surface sediments represent a sink for heavy metals [5].

The aim of this research is to determine a degree of pollution of the River Ibar and to compare the water quality of this river upstream and downstream of two towns, Kosovska Mitrovica and Kraljevo during the period 2010-2016. In the last few decades, the quality of water of the River Ibar has been the subject of numerous researches $[6,7,8,9]$ but none of them used a methodology including determining the spatial and temporal changes.

This research relies on the study done by Milicević et al. [9] and the main objective is to determine whether there are spatial and temporal differences in the physicochemical properties of water and concentrations of heavy metals in water and sediment of the River Ibar upstream and downstream of Kosovska Mitrovica and Kraljevo. The aim of the paper is to propose a model of research that could be applied on the water and sediment analyses in the urban areas. Furthermore, in order to determine the intensity of anthropogenic impact, the obtained results are compared with the values defined by the official regulations of the Republic of Serbia on the limit values of pollutants in the surface and groundwater and sediment.

\section{EXPERIMENTAL PART}

\subsection{Study area}

The River Ibar flows through the southern and central part of Serbia and the eastern part of Montenegro and it belongs to the Black Sea Basin (Fig.1). The total length of the River Ibar is $276 \mathrm{~km}$, and the watershed covers an area of $8,059 \mathrm{~km}^{2}$. The River Ibar springs under the Hajla Mountain in the eastern Montenegro, flows east to Kosovska Mitrovica, and north to Kraljevo where it meets the River West Morava. The water of the Ibar River is used for water supply for about 500.000 inhabitants in towns through which the river flows, therefore monitoring the quality of water of the Ibar River is of the primary importance for determining the contamination of aquatic ecosystem and protection the human health.

The lower River Ibar flows through the territory of the two municipalities of Raška and Kraljevo. In its middle and lower parts, the River Ibar accepts a large quantity of wastewater from the industry, agriculture, municipal landfills, and part of urban waste water which are discharged without any treatment. This is also the main reason why many parameters of the water quality of the River Ibar do not meet the limit values of the II class of water, which should be the case on the basis of the Decree on Categorization of the Watercourses and the Water Classification Regulation ("SRS Official Gazette" No. 5/68).

The confluence of Rivers Sitnica and Ibar is in Kosovska Mitrovica. In this area, the River Ibar flows along several miningmetallurgical-chemical plants and tailings of the Trepča Combine. To the north of Kosovska Mitrovica and Zvečan, about $45 \mathrm{~km}$, the River Ibar flows along the flotation plant of lead-zinc ore and its mines in Leposavić, and after $20 \mathrm{~km}$ in Rudnica also flows near the flotation plant of zinc ore ("Suva Ruda"). About $10 \mathrm{~km}$ kilometers north of Rudnica, and immediately upstream of Raška, the very polluted River Raška flows into the River Ibar. In Raška, the River Ibar is polluted by dairy and meat industry waste water, municipal waste water disposal sites in Raška, Baljevac and surrounding towns. Additionally, the River Ibar is polluted with the waste water of the coal separation processes in Baljevac.

\subsection{Samples}

In this study, the analyses of water and sediment samples of the River Ibar downstream and upstream from Kosovska Mitrovica and Kraljevo were carried out. The water and sediment sampling from the 
Ibar River was conducted during the period 2010-2016, and included four locations: 1) Upstream of Kosovska Mitrovica and $\sim 6 \mathrm{~km}$ downstream from the dam of Gazivode Lake, at the town Zubin Potok
(ZP); 2) Downstream of Kosovska Mitrovica in Veliko Rudare (VR); 3) Upstream of Kraljevo in Konarevo (K); 4) Downstream of Kraljevo in Ratina (R) (Fig. 1).

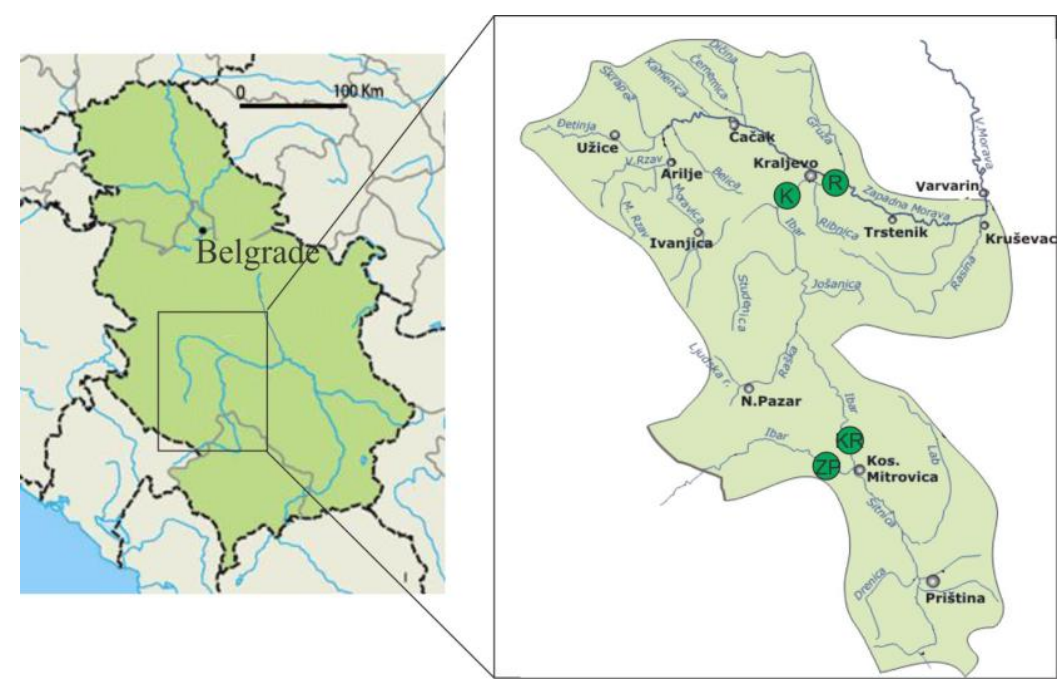

Figure 1 Watershed of the River Ibar with sampling locations: ZP-ZubinPotok, $V R$ - Veliko Rudare, $K$ - Konarevo, $R$ - Ratina

\subsection{Methodology}

The following methods were used for analyses the water samples: $\mathrm{pH}$, suspended matter, biological oxygen demand, chemical oxygen demand, total organic carbon, nitrates, nitrites, ammonium ion, total phosphorous, sulphates, electrical conductivity at $20^{\circ} \mathrm{C}$. Concentrations of heavy metals in the water and sediment samples were determined using an inductively coupled plasma optical emission spectrometry (ICP-OES) using a SPECTRO AR COS instrument.

\subsection{Legislation for surface water and sediments}

The limits of pollutants and methodology of parameters determination in surface water according to the Regulation - Decree on limit values of pollutants in surface and ground water and sediment and deadlines for their reaching (Official Gazette RS, No. $50 / 12$ ), was used as a criteria for pollution determination in the samples from the River Ibar (Class I- water in the natural state or after disinfection can be used as drinking water, Class II - water suitable for recreation, Clas III- water that can be used for industry, Clas IV- unusable water).

\section{RESULTS AND DISCUSSION}

\subsection{Physico-chemical parameters in the River Ibar water}

Screening of water and sediment quality was conducted on selected samples from two locations at the River Ibar. Upstream and downstream of the towns Kosovska Mitrovica and Kraljevo, the physical and 
chemical characteristics $(\mathrm{pH}, \quad$ suspended matter, dissolved oxygen, biological oxygen demand and chemical oxygen demand) of water and concentrations of heavy metals in water and sediment, were determined.

Statistical analyses proved that the water quality decreases from Kosovska Mitrovica to Kraljevo. Concentrations of soluble oxy gen, chlorides, sulphates, nitrates, ortophosphates, ammonium ion and electrical conductivity increase in the River Ibar water downstream from Kosovska Mitrovica to Kraljevo. The results of the $\mathrm{pH}$-value measurement showed that water of the River Ibar is alkaline, indicating the presence of organic waste materials (Table 1).

Table 1 Results of t-test of the River Ibar water samples upstream and downstream of the towns Kosovska Mitrovica and Kraljevo

\begin{tabular}{|c|c|c|c|c|c|c|}
\hline \multirow{2}{*}{ Parameter } & \multicolumn{2}{|c|}{$\begin{array}{c}\text { Kosovska Mitrovica } \\
(\mathbf{n}=21)\end{array}$} & \multicolumn{2}{|c|}{ Kraljevo $(n=19)$} & \multirow{2}{*}{$\begin{array}{l}\text { t val- } \\
\text { ue }\end{array}$} & \multirow{2}{*}{$\begin{array}{l}\text { Significance } \\
\text { (2-tailed) }\end{array}$} \\
\hline & Mean & $\begin{array}{l}\text { Standard } \\
\text { deviation }\end{array}$ & Mean & $\begin{array}{l}\text { Standard } \\
\text { deviation }\end{array}$ & & \\
\hline $\mathrm{pH}$ & 7.96 & 0.36 & 8.20 & 0.14 & -2.80 & 0.01 \\
\hline Soluble oxygen $/ \mathrm{mg} \mathrm{O}_{2} \mathrm{l}^{-1}$ & 8.16 & 3.81 & 11.21 & 1.52 & -3.26 & 0.00 \\
\hline Chlorides / $\mathrm{mg} \mathrm{l}^{-1}$ & 11.95 & 3.72 & 14.11 & 5.31 & -1.50 & 0.14 \\
\hline Nitrates / mg N ${ }^{-1}$ & 1.83 & 0.98 & 2.45 & 0.58 & -2.38 & 0.02 \\
\hline $\begin{array}{l}\text { Electrical conductivity at } \\
20^{0} \mathrm{C} / \mathrm{mS} \mathrm{cm}^{-3}\end{array}$ & 278.32 & 87.14 & 425.79 & 69.80 & -5.87 & 0.00 \\
\hline Orthophosphates $/ \mathrm{mg} \mathrm{Pl}^{-1}$ & 0.03 & 0.04 & 0.10 & 0.04 & -5.27 & 0.00 \\
\hline Sulphates / mg $1^{-1}$ & 10.69 & 15.64 & 25.38 & 7.57 & -3.48 & 0.00 \\
\hline Ammonium ion / $\mathrm{mg} \mathrm{N}^{-1}$ & 0.02 & 0.05 & 0.72 & 0.32 & -10.05 & 0.00 \\
\hline
\end{tabular}

\subsection{Heavy metals in sediment and water \\ from the River Ibar - comparing \\ Kosovska Mitrovica and Kraljevo}

According to the obtained preliminary results, the concentrations of $\mathrm{Cd}$ and $\mathrm{Zn}$ in sediment (Table 2) downstream from Kosovska Mitrovica are five times higher, and As is more than 50 times higher than upstream. Concentrations of copper and mercury decrease downstream, while chromium and iron vary from 2 to $10 \%$. In this part of the watercourse, there are the mine tailings dumps rich in zinc, cadmium and arsenic.
As the concentration of these parameters in the sediment is high, it refers to a longterm source of pollution (probably decennial). This also means that in the future it cannot be expected that the concentration of these ions will decrease in water. Data presented in Table 3 show that the concentrations of heavy metals in water have been significantly increased downstream of Kosovska Mitrovica, which is additionally proves this pollution. 
Table 2 Concentrations of heavy metals in sediment from the River Ibar

\begin{tabular}{|c|c|c|c|c|c|c|c|c|}
\hline \multirow{2}{*}{ Metal } & \multicolumn{4}{|c|}{ Sample mark } & \multicolumn{4}{|c|}{ Legislation values } \\
\hline & $\mathbf{Z P}$ & VR & $\mathbf{K}$ & $\mathbf{R}$ & $1 *$ & $2 *$ & $3 *$ & $4 *$ \\
\hline As /ppm & 4.52 & 220.4 & 56.23 & 39.26 & 29 & 55 & 55 & 55 \\
\hline $\mathrm{Cd} / p p m$ & 0.41 & 5.65 & 2.39 & 1.63 & 0.8 & 2.0 & 7.5 & 12 \\
\hline $\mathrm{Cr} / p p m$ & 61.55 & 63 & 158.33 & 177.47 & 100 & 380 & 380 & 380 \\
\hline $\mathrm{Cu} / p p m$ & 125.8 & 66.11 & 47.82 & 42.23 & 36 & 36 & 90 & 190 \\
\hline $\mathrm{Hg} / p p m$ & 0.14 & 0.02 & 0.53 & 1.06 & 0.3 & 0.5 & 1.6 & 10 \\
\hline $\mathrm{Ni} / p p m$ & 73 & 94.22 & 297.18 & 355.87 & 35 & 35 & 45 & 210 \\
\hline $\mathrm{Pb} / p p m$ & 31.22 & 404.9 & 87.19 & 74.52 & 85 & 530 & 530 & 530 \\
\hline $\mathrm{Zn} / p p m$ & 149.72 & 646.53 & 344.66 & 280.82 & 140 & 480 & 720 & 720 \\
\hline
\end{tabular}

*1. Target value: Concentrations of pollutants in sediment are at the level of natural background. Sediments can be dislocated without special protection measures; $2 *$ Limit value: Sediment is slightly polluted. Disposal is allowed without the special protection measures; $3 *$. Sediment is contaminated. Its disposal is not allowed without the special protection measures. It is necessary to store in the controlled conditions with special protection measures on preventing the spread of pollutants into the environment; 4*. Extremely polluted sediments. Remediation is mandatory or keeping the stuffed material in the controlled conditions with the special protection measures to prevent it Spreading of polluted substances into the environment

At the Kraljevo site, the concentrations of arsenic, barium, cadmium and zinc decrease 2 to 3 times downstream, while only the mercury concentration increases doubly. Concentrations of other metals vary in the range of 2 to $10 \%$. The obtained results indicate that during removal of sediments downstream of Kosovska Mitrovica and Kraljevo, it has to be treated as a hazardous waste under rather demanding conditions (a sealed landfill with hazardous waste treatment) due to the increased concentrations of nickel, arsenic and mercury. The concentrations of lead, cadmium and zinc are close to the legal limits, and in the future, given the accumulation in sediment, it can be expected that the concentration exceed limits defined in Table 2. Removal of sediments with increased concentrations of heavy metals is necessary for reduction the concentration of certain heavy metals in water.

Based on the obtained values for heavy metals in water of the River Ibar, given in Table 3, it can be concluded that the concentrations of arsenic, iron, manganese and zinc increase downstream from Kosovska Mitrovica from three to ten times (three times $\mathrm{Zn}$, from five to six times As and Fe, while Mn increases ten times), only the concentration of mercury decreases. Upstream from Kosovska Mitrovica concentrations of $\mathrm{Cd}$, $\mathrm{Cr}, \mathrm{Cu}, \mathrm{Ni}, \mathrm{Pb}$ are below the detection limit. This is in accordance with above statement about influence of landfills in Kosovska Mitrovica rich in heavy metals. The obtained concentrations for the area of Kraljevo show that there are no major deviations downstream and upstream from the town.

Table 3 Concentrations of heavy metals in water samples (ppb)

\begin{tabular}{|c|c|c|c|c|c|c|c|c|c|c|}
\hline $\begin{array}{c}\text { Sampling } \\
\text { location }\end{array}$ & As & Cd & $\mathbf{C r}$ & $\mathbf{C u}$ & $\mathbf{F e}$ & $\mathbf{H g}$ & $\mathbf{M n}$ & $\mathbf{N i}$ & $\mathbf{P b}$ & $\mathbf{Z n}$ \\
\hline ZP & 1.12 & LOD & LOD & LOD & 66.02 & 4.15 & 11.35 & LOD & LOD & 45.59 \\
\hline VR & 5.21 & 0.65 & 1.91 & LOD & 422.7 & 2.79 & 123.9 & 7.06 & 1.04 & 180.8 \\
\hline K & 5.87 & 0.28 & 5.01 & LOD & 586.4 & 2.03 & 73.28 & 14.9 & 6.59 & 76.96 \\
\hline R & 6.03 & 0.29 & 4.7 & LOD & 597.7 & 2.02 & 71.45 & 18.13 & 9.96 & 72.6 \\
\hline
\end{tabular}

*According to the Decree on limit values of pollutants in surface and ground water and sediment and deadlines for their reach, (Official Gazette RS, No. 50/12); LOD - bellow limit of detection 
One of the major mechanisms of accumulation the heavy metals in sediments is an interaction with the organic matter. Mobilization of $\mathrm{Zn}$ and $\mathrm{Pb}$ is affected by a higher concentration of $\mathrm{Mn}$ in sediment (Table 2). Significantly increased heavy metal concentrations of $\mathrm{Pb}$ and $\mathrm{Zn}$ originate from the mining-metallurgical-chemical combine of lead and zinc Trepča. Pollution associated with the mining contamination of sulphate ore deposit, such as Trepča, could result in a high concentrations of sulphate ions in water, however, the obtained results do not show it (Table 1).

\subsection{Physico-chemical properties of the River Ibar water in Kraljevo}

As indicated above, the obtained results indicate that the River Ibar water has a poo- rer quality in Kraljevo than in Kosovska Mitrovica. Therefore, a data set containing 14 parameters, determined in 47 water samples, collected during the period 2010-2016, was analyzed to determine the spatial and temporal differences. Spatial analyses included a comparison of the physicochemical parameters upstream and downstream of Kraljevo, and temporal included both annual and seasonal comparison.

The upstream and downstream samples from Kraljevo do not show a statistically significant difference in the water quality in any of tested parameters (Table 4). This indicates that there are no major pollution sources in the town of Kraljevo. This also indicates that the reason for water quality decrease in Kraljevo is a consequence of pollution along the river section between two towns.

Table 4 Results of physical and chemical analysis of water from the River Ibar sampled upstream and downstream and results of t-test and during period 2010-2016 in Kraljevo and ANOVA results

\begin{tabular}{|c|c|c|c|c|c|c|c|c|c|c|c|c|c|}
\hline & $\begin{array}{l}\text { Upstream } \\
(\mathrm{n}=27)\end{array}$ & $\begin{array}{l}\text { Downstream } \\
(\mathrm{n}=20)\end{array}$ & $\mathrm{t}$ value & $\begin{array}{l}\text { Significance } \\
\text { (2-tailed) }\end{array}$ & 2010 & 2011 & 2012 & 2013 & 2014 & 2015 & 2016 & $\begin{array}{c}F \\
\text { value }\end{array}$ & $\begin{array}{l}\text { Signifi- } \\
\text { cance }\end{array}$ \\
\hline Temperature $/{ }^{\circ} \mathrm{C}$ & 10.39 & 10.73 & -0.15 & 0.88 & 13.04 & 11.22 & & 14.45 & 14.8 & 11.16 & 11.9 & 6.53 & 0 \\
\hline $\begin{array}{l}\text { Soluble oxygen/ } \\
\mathrm{mgO}_{2} / 1\end{array}$ & 11.04 & 10.24 & 1.05 & 0.3 & 11.01 & 7.58 & 11.15 & 11.68 & 10.44 & 12.03 & 11.33 & 2.59 & 0.03 \\
\hline $\mathrm{pH}$ & 8.12 & 8.05 & 1.11 & 0.27 & 8.01 & 7.85 & 8.16 & 7.98 & 8.21 & 8.23 & 8.14 & 3.01 & 0.02 \\
\hline $\begin{array}{l}\text { Electrical } \\
\text { conductivity at } 20 \\
{ }^{0} \mathrm{C} / \mathrm{mScm}^{-3} \\
\end{array}$ & 422.91 & 439.07 & -0.79 & 0.44 & 423.75 & 440.83 & & 437.25 & 404.38 & 450.14 & 426 & 0.48 & 0.79 \\
\hline Nitrates $/ \mathrm{mgN} /$ & 2.29 & 2.34 & -0.21 & 0.84 & 2.04 & 2.06 & 1.95 & 3.31 & 2.61 & 2.31 & 2.37 & 2.07 & 0.08 \\
\hline Nitnites $/ \mathrm{mgN} / 1$ & 0.03 & 0.04 & -0.71 & 0.48 & 0.02 & 0.06 & & 0.06 & 0.03 & 0.03 & 0.03 & 0.79 & 0.56 \\
\hline $\begin{array}{l}\text { Ammoniumion/ } \\
\mathrm{mgN} / 1\end{array}$ & 1.25 & 0.88 & 0.48 & 0.64 & 0.47 & 0.66 & 1.09 & 4.83 & 0.78 & 0.77 & 0.54 & 1.92 & 0.1 \\
\hline Chlonides $/ \mathrm{mg} / \mathrm{l}$ & 18.74 & 15.23 & 0.7 & 0.49 & 15.38 & 16.33 & 17.5 & 15.94 & 14.73 & 12.47 & 39.8 & 1.91 & 0.11 \\
\hline $\begin{array}{l}\text { Chemical oxygen } \\
\text { demand } / \mathrm{mgO}_{2} \mathrm{~A}\end{array}$ & 6.49 & 6.29 & 0.1 & 0.92 & 7.15 & 4.93 & & 14.08 & 4.05 & 4.83 & 7 & 2.14 & 0.09 \\
\hline $\begin{array}{l}\text { Biological } \\
\text { oxygen demand } / \\
\mathrm{mg} \mathrm{O}_{2} / 1\end{array}$ & 3.95 & 8.61 & -1.45 & 0.15 & 3.33 & 2.35 & 18.33 & 6.45 & 2.99 & 1.94 & 2.8 & 2.91 & 0.02 \\
\hline Sulphates $/ \mathrm{mg} / \mathrm{l}$ & 28.75 & 27.54 & 0.41 & 0.68 & 29.73 & 29.83 & & 36.93 & 22.27 & 29.59 & 24.24 & 2.25 & 0.07 \\
\hline $\begin{array}{l}\text { Orthophosphates } \\
/ \mathrm{mg} \mathrm{P} \mathrm{/}\end{array}$ & 0.16 & 0.1 & 0.74 & 0.46 & 0.05 & 0.15 & 0.1 & 0.54 & 0.12 & 0.07 & 0.1 & 1.98 & 0.09 \\
\hline $\begin{array}{l}\text { Suspendedmatter } \\
/ \mathrm{mgl}\end{array}$ & 16.97 & 14.3 & 0.73 & 0.47 & 10.5 & 9.57 & & 22 & 14.25 & 20.86 & 25.25 & 2.46 & 0.05 \\
\hline $\begin{array}{l}\text { Total organic } \\
\text { carbonmg/ }\end{array}$ & 1.91 & 5.96 & -1.37 & 0.18 & 2.2 & 1.06 & 11.1 & 2.43 & 1.9 & 1.81 & 2.13 & 0.97 & 0.46 \\
\hline
\end{tabular}


Temporal comparison showed differences in the River Ibar water samples from Kraljevo. During the time period 2010 - 2016, the water quality changed significantly regarding the following pa- rameters: temperature, soluble oxygen, $\mathrm{pH}$ and biological oxygen demand (Table 4, Fig. 2) which are probably connected to the climate variations during this time period.
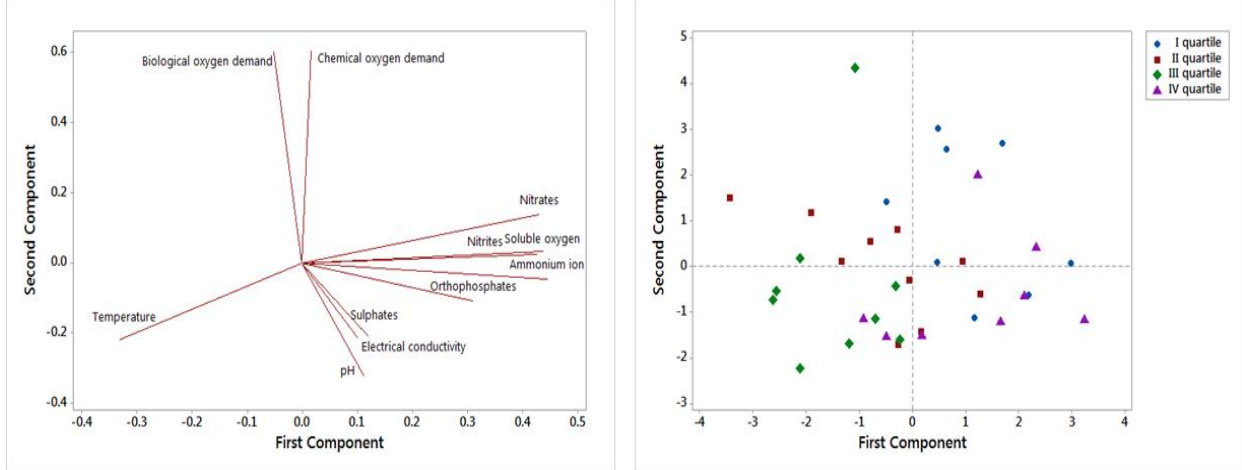

Figure 2 Principal component analyses of seasonal change physico-chemical parameters in the River Ibar water samples

Large flow changes, as well as statistically significant change in water temperature, necessarily lead to a change in the solubility of oxygen. The present oxidable substance will therefore also affect the chemical oxygen demand and biological oxygen demand (Table 4). Decreased oxygen concentration, and increased concentrations for chemical oxygen demand and biological oxygen demand indicate the anthropogenic and industrial contamination.

An important change was observed comparing the water quality over seasons during the observed period (2010-2016). Large flow changes are characteristic for this river [10]. During colder months, represented by I and IV quartiles, the water samples had higher concentrations of ortophosphates, nitrates, nitrites (anthropogenic contamination source) as well as soluble oxygen since it increases with the water temperature decrease (Fig. 2, Table 4). During warmer months, II and III quartiles, water expectedly had higher temperature, and higher biological oxygen demand due to a growth of water biomass. During spring- summer change the water electrical conductivity, $\mathrm{pH}$ and concentration of sulphates has most prominent change (Fig. 2).

\section{CONCLUSIONS}

The River Ibar from the spring to the confluence of the West Morava accepts wastewater in a direct or indirect way from is influenced by the population, economy with entire infrastructure, waste materials, etc.

Significantly increased of heavy metal concentrations above target values $\mathrm{Pb}$ and $\mathrm{Zn}$ in Kosovska Mitrovica come from the mining-metallurgical-chemical combination of lead and zinc Trepča. Sediment in almost all samples has concentrations of $\mathrm{Ni}, \mathrm{Cu}$ and As above the target values, and concentration of $\mathrm{Hg}$ is above target value in samples from Kraljevo.

The water of the River Ibar after flowing through Kraljevo generally shows a higher degree of pollution than in Kosovska Mitrovica. However, this study proved that the water upstream and downstream of 
Kraljevo is of lower quality indicating that the pollution source is not in located in Kraljevo, but along the river stretch between the two towns.

This study has also proved that the water quality did not significantly change during the period 2010-2016, except regarding the following parameters: temperature, $\mathrm{pH}$, soluble oxygen and biological oxygen demand which is probably a consequence of climate variations during this time period. Most important conclusion is connected to seasonal changes in the water quality in Kraljevo. The highest concentrations of nitrates, nitrites, ortophosphates and ammonium ion were found in colder months (I and IV quartile). During spring-summer change electrical conductivity, $\mathrm{pH}$ and concentration of sulphates has most prominent change in analyzed Ibar River waters in Kraljevo.

In this paper the geochemical and physico-chemical parameters were used to determine the temporal and spatial changes of water and sediment quality in the River Ibar from Kosovska Mitrovica and Kraljevo. The proposed approach should be used in Kosovska Mitrovica and other urban locations along the Ibar River, as well as the other watercourses, for both temporal and spatial proper identification of pollution points.

\section{REFERENCES}

[1] Singh, K.P., Malik, A., Mohan, D., Sinha, S. (2004) Multivariate Statistical Techniques for the Evaluation of Spatial and Temporal Variations in Water Quality of Gomti River (India) A Case Study, Water Research, 38, 3980-3982

[2] Kristoforović-Ilić, M., Radovanović, M., Vajagić, L., Jeftić, Z., Folić, R., Krnjetin, S., Obrknežev R. (1998) Communal Hygiene, Prometej, Novi Sad, Serbia
[3] Iticescu, C., Georgescu, P. I., Topa, C. Murariu, G (2014) Monitoring the Danube Water Quality near Galati City. J. Environmental Protection Ecology, 15(1), 30

[4] Moga, M., Ples, L., Bigiu, N., Manitiu, I. (2011) An Overview of the Risk of Adverse Reproductive and Developmental Disorders Due to Exposure to Pesticides. J Environ Prot Ecol, 12, 3A, 1311

[5] K.C. Cheung, C.K., T.Poon, H.B., Lan, Y.C.,Wong, H.M.(2003) Assessment of Metal and Nutrient Concentrations in River Water and Sediment Collected from the Cities in the Pearl River Delta, South China, Chemosphere 52 1431-1440

[6] Marinović, D.D., Savić, M.V., Stojanović, T.M., Popović, B.D., V. B. Nikolić-Vujačić, B.V., Nikolić, B.S.(2015) Quality of the River Ibar from Biljanovac to Kraljevo, Tehnika, 70, 188

[7] Marinović, D.D., Dimitrijević, M.Z., Stojanović, T.M., Nikolić, B.S. (2016) Waste Water Treatment Plant City of Kraljevo, Tehnika, 71, 926-933

[8] Milićević, Z., Marinović, D., Gajica, G., Kašanin-Grubin, M. Jovanović, B., Jovančićević, B. (2017) Organic Geochemical Approach in the Identification of Oil-type 2 Pollutants in Water and Sediment of the River J. Serb. Chem. Soc, 82(5), 593-605

[9] Marković, M.S. (2016) Comparative Analysis of Communal Wastewater in the Area of Zubin Potok, Kosovska Mitrovica and Zvecan, Ecologica, 83, 511-514

[10] Jaćimović, N., Kostić, D., Grašić, S., Nenadić, N. (2014) Analysis of the Impact of the Construction of the Hydroelectric Power Plant Ibar on Water Quality, Vodoprivreda, 46, 163178 . 